\title{
Mesenchymal Stem Cells Derived Extracellular Vesicles Ameliorate Cortical Cerebellar Changes-induced by Aspartame in Rats, Original Histological and Immunohistochemical Study
}

Article

\author{
Rania Ebrahim El Desoky and Ola Mostafa Mohamed
}

Histology and Cell Biology Department, Faculty of Medicine, Benha University, Egypt

\begin{abstract}
Background: Exosomes are endogenous nanovesicles that cooperate key roles in intercellular signaling by bearing functional genetic information and proteins between cells. Exosomes speedily cross the blood-brain barrier and have indicated as therapeutic approach vehicles that have the potential to specifically deliver molecules to the central nervous system (CNS). Aspartame (ASP) is applied in many products. ASP has been interconnected to cause neurological and behavioral changes such as headache, insomnia, and seizures.

Aim: Aim of this study was to determine the potential role of exosomes on cerebellar changes caused by aspartame (ASP). Materials and Methods: Thirty five adult male albin0 rats were divided into three gr0ups. The first group served as the c0ntrol group. In the second group, the rats were given ASP orally at a d0se of $250 \mathrm{mg} / \mathrm{kg} / \mathrm{day}$ for 6 weeks. In the third group, the rats were given ASP as group II plus exosomes in a d0se of $100 \mathrm{mg} / \mathrm{kg}$ intravenously/twice per week. At the end of the 6 th week of the experiment cerebellar specimens were appr0priated for histological and immuno-histochemical studies.

Results: In the ASP-treated group, dis0rganization of the three layers of the cerebellar c0rtex was observed. Spaces were seen between the cells. Small pykn0tic nuclei of Purkinje cells and deformed cells were also detected . Furthermore, there was a significant increase $(p \leq 0.01)$ of GFAP, COX-2 and caspase- 3 immune expression compared with control group. Ex0somes in conjunction with ASP resulted in impr0vement in the organization of cellular layers of the cerebellar c0rtex with a significant decrease $(p \leq 0.01)$ of GFAP, COX-2 and caspase-3 immune expressi0n compared with group II.

Conclusion: Exosomes ameli0rates the neuropathological changes caused by aspartame on the structure of the cerebellar cortex of albin0 rats.
\end{abstract}

Received: 06 October 2019, Accepted: 13 October 2019

Key Words: Aspartame, cerebellum, exosomes.

Corresponding Author: Rania Ebrahim El-Desoky, PhD, Department of Histology and Cell Biology, Faculty of Medicine, Benha Univirsty, Egypt, Tel.: +20 1552997711, E-mail: doc.rania@yahoo.com

ISSN: $1110-0559$, Vol. 43, No.2

\section{INTRODUCTION}

Many peoples used to consume artificial sweeteners to reduce sugar consumption and decrease caloric intake. Healthy individuals, diabetic patients and overweights ingest aspartame (ASP) as it had nearly 200 fold higher sweetness than sucrose ${ }^{[1]}$. Aspartame is a methyl ester of a dipeptide (L-aspartyl- L-phenylalanine methyl ester). It enters in the components of various foods and drinks ${ }^{[2]}$. ASP is hydrolyzed to three components: phenylalanine, aspartate and methanol. Each solitary of these components are toxic and disturb different body organs mainly the central nervous system ${ }^{[3]}$.

Consumption of ASP in large doses have aggressive and harmful effect on the structure of the cerebellar cortex of the albino $\operatorname{rats}^{[5]}$. ASP consumption might result in seizures, memory loss, dizziness, headaches and behavioral changes ${ }^{[4]}$. ASP was hydrolyzed to form phenylalanine, aspartic acid and methanol. Each element result in different neurological and behavioral maladies ${ }^{[6]}$.
In addition, these pathologic changes may be due to the fact that ASP can penetrate the blood-brain barrier and cause neurotoxicity of brain cells resulting in brain damage ${ }^{[7]}$ and many neurological disorders such as persistent headache, Alzheimer and seizures ${ }^{[8]}$.

Novel approaches using different types of stem cells have been projected to treat common neurodegenerative disorders such as Alzheimer's Disease, Parkinson's Disease, or stroke. Moreover, exosomes of these cells exists to be of greater value compared to the cells themselves ${ }^{[9]}$. Exosomes have lately been tested in vivo and in vitro for the treatment of diseases. As such, they could be engineered to target specific populations of the CNS cells ${ }^{[10]}$.

Exosomes, the extracellular nanovesicles can be isolated from all body fluids and have a paracrine mechanism for cell-to-cell communication. They carry a complex cargoconsisting of various types of RNA (ribosomal RNAs, long noncoding RNAs, and microRNAs), proteins, lipids, and $\mathrm{DNA}^{[11-12]}$. 
Exosomes are critical players in intercellular communication that can primarily affect various physiological functions at targeted cells. Exosomes are generated within the cells from multivesicular bodies (MVB) and released into extracellular space via exocytosis ${ }^{[9]}$. These membrane enveloped nanovesicles conduct genetic material, proteins and lipids. They are engaged in regulation of targeted cells and travel in extracellular body fluids to act on nearby cells, in addition to distant targets ${ }^{[11]}$.

Aim of the work is to study the therapeutic effects of exosomes on cerebellar cortex changes induced by ASP. aspartame (ASP) was used as a model of degenerative diseases of the cerebellum .

\section{MATERIALS AND METHODS}

\subsection{Reagents}

- MSC-derived exosomes were achieved from Alkasr-Aliny biochemistry department. The protein content of the exosome pellet was quantified by the Bradford method (BioRad, Hercules, CA, USA) ${ }^{[13]}$. The dose of injected exosomes was adjusted to $100 \mathrm{mg}$ protein/suspended in $0.2 \mathrm{ml}$ phosphatebuffered saline (PBS) ${ }^{[14]}$.

- Aspartame was purchased from sigma company. It was given by intragastric tube in a dose of $250 \mathrm{mg} / \mathrm{rat} /$ day dissolved in tap water ${ }^{[15]}$.

\subsection{Experimental animals}

Thirty five mature male albino rats (180-200 g), were obtained from the Animal Unit, Faculty of Veterinary Medicine, Benha University, Egypt. The rats were bred and maintained in an air-conditioned animal house and specific pathogen-free conditions. All animals were accommodated in clean cages and donated a standard diet and clean water ad libitum. Rats were subjected to a normal light/dark cycle (12-h light-dark cycle starting at 8:00 AM) and room temperature $\left(23 \pm 3^{\circ} \mathrm{C}\right)$. This study was carried out in strict accordance with the recommendations in the Guide for the Care and Use of Laboratory Animals of the National Institutes of Health. All protocols were approved by the institutional review board for animal experiments of the Faculty of Medicine, Benhha University, Egypt.

\subsection{Experimental design and treatment protocol}

Rats were divided into three groups as follow:

Group I (Control group): 15 rats were subdivided equally into 3 subgroups:

Subgroup A: rats placed without any intervention.

Subgroup B: they were given distilled water daily by intragastric tube for 6 weeks.

Subgroup C: they were intravenously injected with 0.2 $\mathrm{mL}$ phosphate-buffered saline (PBS), once per week, for 6 weeks (vehicle for exosomes).
Group II (ASP group): 10 rats were given aspartame daily for 6 weeks. It was given by intragastric tube in a dose of $250 \mathrm{mg} / \mathrm{rat} /$ day dissoved in tap water ${ }^{[15]}$.

Group III (ASP+ exosomes group): 10 rats were given aspartame daily for 6 weeks as group II. Rats were treated with two injections of exosomes through the tail vein $^{[12]}$ once per week for 6 weeks, from the start of the experiment until the end.

At the end of the 6 weeks, rats were sacrificed and cerebellum were resected out. The sections were fixed in $10 \%$ buffered formal saline and processed for paraffin sections of 4-6 $\mu \mathrm{m}$ thickness, mounted on glass slides for $H \& E^{[16]}$. Correspondingly, immunohistochemical evaluation for GFAP, COX2 and caspase-3 were performed $^{[17]}$.

\subsection{Preparation of MSC-Derived Exosomes}

MSC-derived exosomes were achieved from the supernatant of MSCs, representing conditioned media. First, rat bone marrow-derived MSCs (BM-MSCs) were primed in the Central Lab, Faculty of Medicine, Benhha University ${ }^{[10]}$. The MSCs were cultured in Dulbecco's Modified Eagle Medium (DMEM) with $0.5 \%$ human serum albumin (HSA) (Sigma-Aldrich, St. Louis, MO, USA), overnight. The viability of the cells cultured overnight was extra than $99 \%$, as identified by trypan blue exclusion. Cells were plated at 4000 cells/cm2 exactly 10 days. On last day, cells were trypsinized, counted, and replated in expansion medium at a density of 2000 cells $/ \mathrm{cm} 2$ for additional ten days (end of passage 1). The expansion was implemented until the third passage.

The conditioned medium was stored at $-80{ }^{\circ} \mathrm{C}$. The medium was centrifuged at $2000 \mathrm{~g}$ for $20 \mathrm{~min}$ and remove debris, then ultra-centrifuged at $100,000 \mathrm{X} \mathrm{g}$ in a SW41 swing rotor (Beckman Coulter, Fullerton, CA, USA) for one hour at $4{ }^{\circ} \mathrm{C}$. Exosomes were washed with serum-free M199 (Sigma-Aldrich) comprising $25 \mathrm{mM}$ 4-(2-hydroxyethyl)-1-piperazineethanesulfonic acid (HEPES) $(\mathrm{pH}=7.4)$, and proposed to a second ultracentrifugation in the identical way.

\subsection{Localization of MSCs-EVS}

Exosomes were isolated from the supernatant of the first, second, and third passages of MSCs cultured in alpha-MEM. The MSC-derived exosomes were fixed with $2.5 \%$ glutaraldohyde in HSA for $2 \mathrm{~h}$. After washing, exosomes were ultracentrifuged and suspended in 100 mL HSA. An absolute of $20 \mathrm{~mL}$ of exosomes was loaded onto a formvar/carben-coated grid, negatively stained with $3 \%$ aqueous phospher-tungstic acid for $1 \mathrm{~min}$, and observed by transmission electron microscopy (Hitachi H-7650, Hitachi, Tokyo, Japan $)^{[1]}$. Additionally, PKH26 (Sigma-Aldrich, St. Louis, MO, USA) was used to confirm the exosome localization within the cerebellum. The exosome pellet was diluted with PKH-26 kit solution to $1 \mathrm{ml}$, and $2 \mathrm{ml}$ of fluorochrome was added to this 
suspension and incubated at $38.5{ }^{\circ} \mathrm{C}$ for $15 \mathrm{~min}$. After that, $7 \mathrm{~mL}$ of serum-free HG-DMEM was appended to the suspension, then it was ultracentrifuged for second time at $100,000 \mathrm{Xg}$ for $1 \mathrm{~h}$ at $4{ }^{\circ} \mathrm{C}$. The final pellet was resuspended rapidly in HG-DMEM and stored at $-80{ }^{\circ} \mathrm{C}$ for future injection in experimentally rats ${ }^{[14]}$.

\subsection{Immunohistochemistry study}

Serial paraffin sections of $5 \mu \mathrm{m}$ thick were deparaffinizzed and dehydrited, The endogenous peroxidase activity was blocked with $0.05 \%$ hydrogen peroxide in absolute alcohol for 30 minutis. The slides were washed $5 \mathrm{~min}$ in phosphite buffered saline (PBS) at $\mathrm{PH}=7.4$. To unmask the antigenic spots, sections were put into $0.01 \mathrm{M}$ citrate buffer $(\mathrm{PH}=6)$ in the microwave for $5 \mathrm{~min}$. The slides were incubated in $1 \%$ bovin serum albumin dissolved in PBS for $30 \mathrm{~min}$ at $37^{\circ} \mathrm{C}$ with the purpose of prevent the nonspecific background staining. Two drops of ready to use primary antibody for Glial fibrillary acidic protein (GFAP) of glial cells (purchased from Lab vision, USA), anti-rabbit, anti-mouse polyclonal COX-2-specific IgG (SAB4200576; Sigma) and Caspase-3 (CPP-32, Apoptain, Yama, SCA-1) ${ }^{[17]}$ were applied to sections, except for negative control, then they were incubited for one hour and half at room temperature. The slides were rinsed with PBS, then incubated for one hour with anti-mouse immunoglobulins (secondary antibody) conjugated to peroxidase labeled dextran polymer (AKO, Denmark). With the aim of detect the reaction, the slides were incubated in 3,3-diaminobenzidene (DAB) for $15 \mathrm{~min}$. The slides were counterstained by Mayer's Haematexylin, then dehydrated, cleared and mounted by DPX11.

\subsection{Morphometric study and Statistical analysis}

The mean area\% of GFAP, COX2 and caspase-3 expression were quantified in 10 images for cerebellar cortex sections from 10 rats of each group using ImagePro Plus program, version 6.0 (Media Cybernetics Inc., Bethesda, Maryland, USA). Statistical analysis was performed using the statistical software package SPSS for Windows (Version 22; SPSS Inc., Chicago, IL, USA). Evaluation of differences between groups was performed using one-way ANOVA with post HOC test (LSD). In each test, all the data are presented as mean \pm standard deviation (SD), and $P$ value $<0.01$ was considered significant.

\section{RESULTS}

\subsection{Exosome Characterization}

A transmission electron microscopy examination of purified exosomes in vivo demonstrated their characteristic spheroid double-membrane bound morphology with a diameter of $30-90 \mathrm{~nm}$ (Figure 1). The exosomes were detected in cerebellar tissues by PKH26 dye tracing (Figure 2).

\subsection{Haematoxylin and Eosin results}

Cerebellar cortex of the three subgroups of group I (control group) showed similar results. It was formed of three layers. Outer molecular layer, formed of few scattered cells with many nerve fibers and dendrites. Middle Purkinje cell layer appeared as a single continuous layer of large cells at the junction of superficial molecular and deep granular layers. Purkinje cells appeared with large flask shaped cell bodies contained rounded pale stained nuclei with prominent nucleoli. Inner granular layer, of densely packed nuclei of numerous granular cells. (Figure 3). ASP group showed, empty spaces appeared between cells of the granular layer. Most of the Purkinje cells appeared deformed and shrunken losing their characteristic pyriform shape. Some of them showed deeply stained condensed nuclei. Halo of empty spaces appeared around the Purkinje cells which was dilatation of the perineural space. Granular layer having cells with very dense nuclei separated by empty spaces between them (Figure 4). Exosomes + ASP group showed no spaces in the granular layer between cells. Purkinje cells regained their pyriform shape and their nuclei appeared vesicuolar. They appeared with large flask shaped cell bodies contained rounded pale stained nuclei with prominent nucleoli. The superficial molecular layer, was formed of few scattered cells with many nerve fibers and dendrites and deep granular cell layer, of densely packed nuclei (Figure 5).

\subsection{Immunohistochemistry results}

\subsubsection{Immunohistochemical staining for GFAP}

Positive reaction appeared brown in color for glial cells. Control group showed few small sized GFAP positive cells (astrocytes) with short processes in the three layers of cerebellar cortex (Figure 6). Aspartame group showed increased intensity of the reaction, apparently increased size of cell body, number and length of their processes with strong expression of GFAP (Figure 7). Exosomes + ASP group showed smaller sized GFAP positive cells (astrocytes) than in group II with short processes (Figure 8).

\subsubsection{Immunohistochemical evaluation for cyclooxygenase 2}

Positive immunostaining gave cytoplasmic brown granules indicating inflammation. Sections of the control group showed few immune reaction for COX 2 (Figure 9).The ASP treated group showed, a strong positive COX 2 reaction (Figure 10). While the COX 2 immunoreaction was mild in group III (ASP + exosomes group) (Figure 11).

\subsubsection{Immunohistochemical staining for caspase -3}

Positive immun0histochemical staining of capsase-3 was demonstrated as brown cytoplasmic reaction in apoptotic cells. In Group I (control group), there was scant cytoplasmic immune reactivity for caspase-3 (Figure 12). Group II (ASP group) showed strong cytoplasmic immune reactivity for caspase-3 (Figure 13). While group III (exosomes + ASP group) showed mild cytoplasmic immune reactivity for caspase-3 (Figure 14). 


\subsection{Morphometric results}

The mean area $\%$ and standard deviation (SD) of GFAP, COX2 and caspase-3 immuno-expression for all groups was represented in (Tables 1,2 and 3) and (Histograms 1,2 and 3). There was a significant increase $(P \leq 0.01)$ in mean area $\%$ of GFAP, COX2 and caspase- 3 immuno-expression of group II (ASP group) compared with group I. There was a significant decrease $(P \leq 0.01)$ in mean area \% of GFAP, COX2 and caspase- 3 immuno-expression of group III (Exosomes+ ASP group) compared with group II (ASP group).

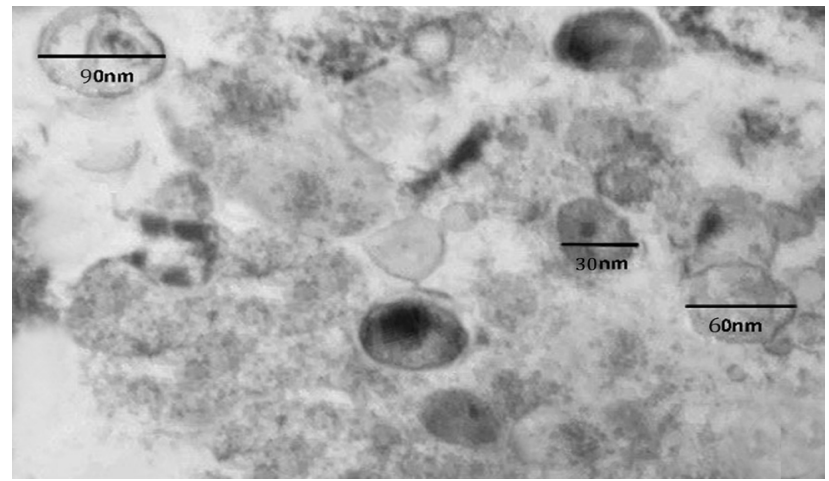

Fig. 1: An electron micrograph of ex0somes in viv0 showing a spheroid double membrane vesicles bound morphology with a diameter of $30-90 \mathrm{~nm}$.

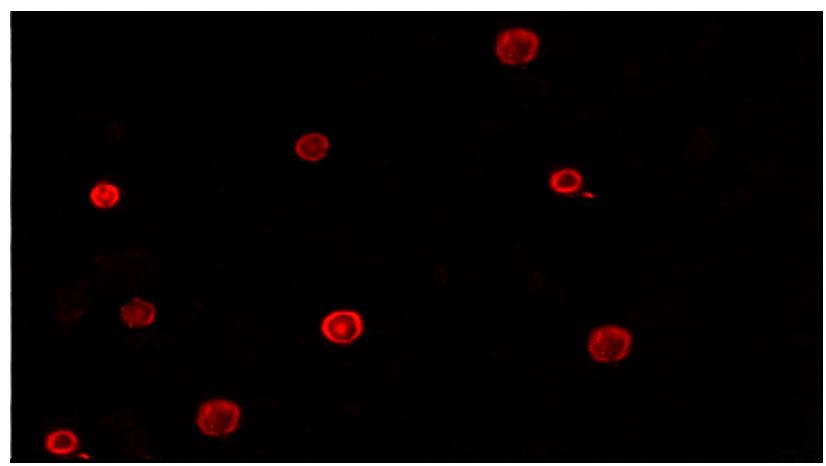

Fig. 2: A photomicrograph in a section of the cerebellum of group III (exosomes +ASP) showing its fluorescent dye by PKH26

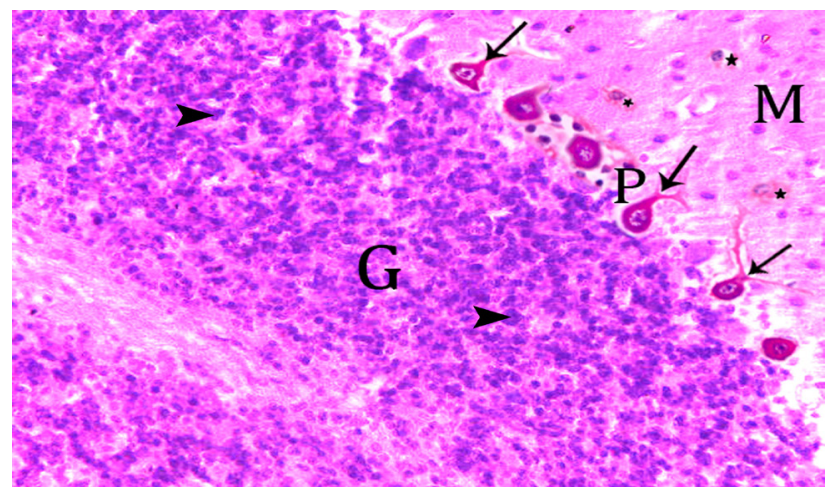

Fig. 3: A photomicrograph of a section in the cerebellar cortex of a rat from group I (control group) showing; molecular layer (M) with few scattered cells (stars), Purkinje cell layer (P), Purkinje cells appear as large pyriform cells arranged in single row (arrow) and granular cell layer(G) appears as tightly packed small cells with deeply stained nuclei (head arrow). (H\&E X400)

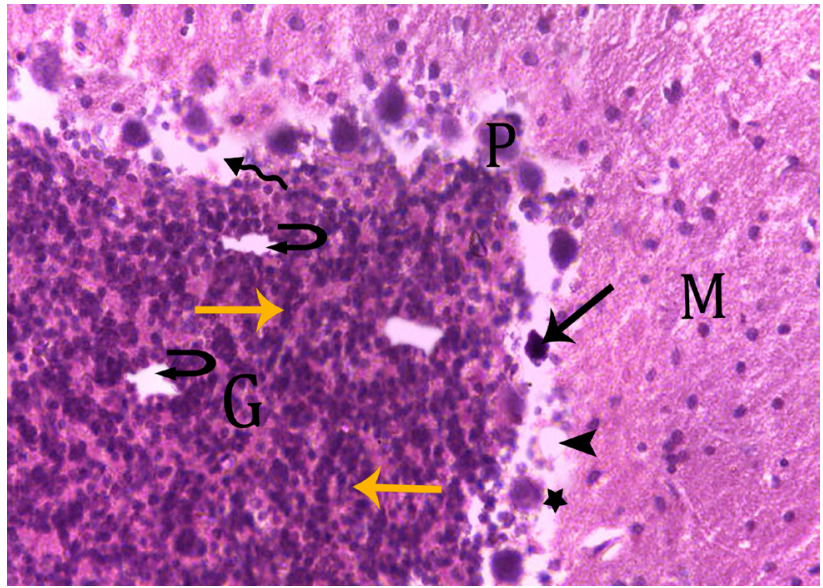

Fig. 4: A photomicrograph of a section in the cerebellar cortex of a rat from group II (ASP group) showing; molecular layer (M) with many scattered cells. Purkinje cell layer (P) with deformed cells (star) and deeply stained shrunken Purkinje cells with pyknotic nuclei (arrow), dilatation of perineural space (head arrow). Notice empty spaces between cells of the granular layer (curved arrow) and in Purkinje cell layer (zigzag arrow). Granular layer (G) having cells with dense nuclei (yellow arrow). (H\&E X400)

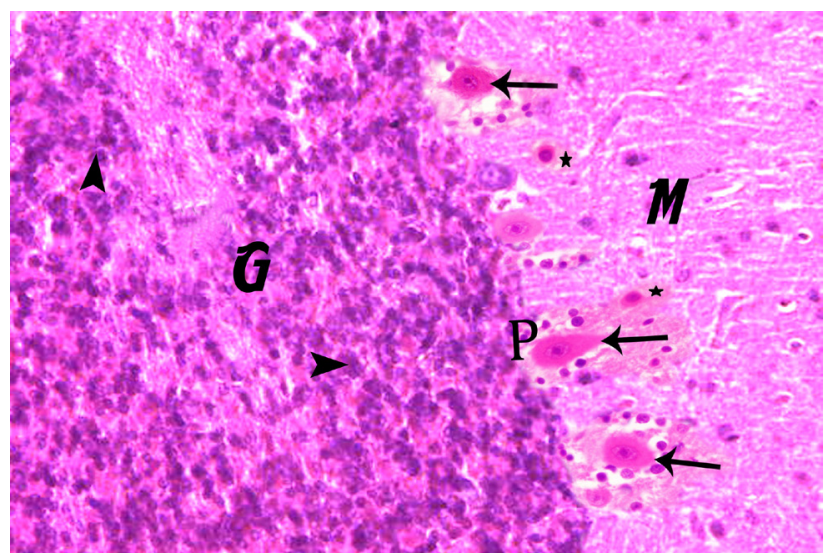

Fig. 5: A photomicrograph of a section in the cerebellar cortex of a rat from group III (ASP+ exosomes group) showing; molecular layer (M) with many scattered cells (stars). Purkinje cell layer (P) showing purkinje cell apparently nearly normal shape (arrow) and granular cell layer (G) with deeply stained nuclei (head arrow). (H\&E X400)

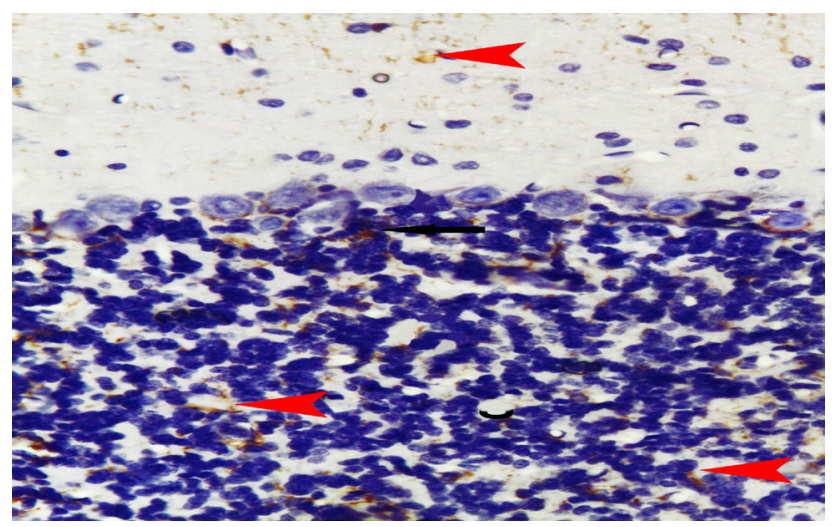

Fig. 6: A photomicrograph of a section in cerebellar cortex of a rat from group I (control group) showing few GFAP positive astrocytes (head arrow) (Immunohistochemistry stain for GFAP X400) 


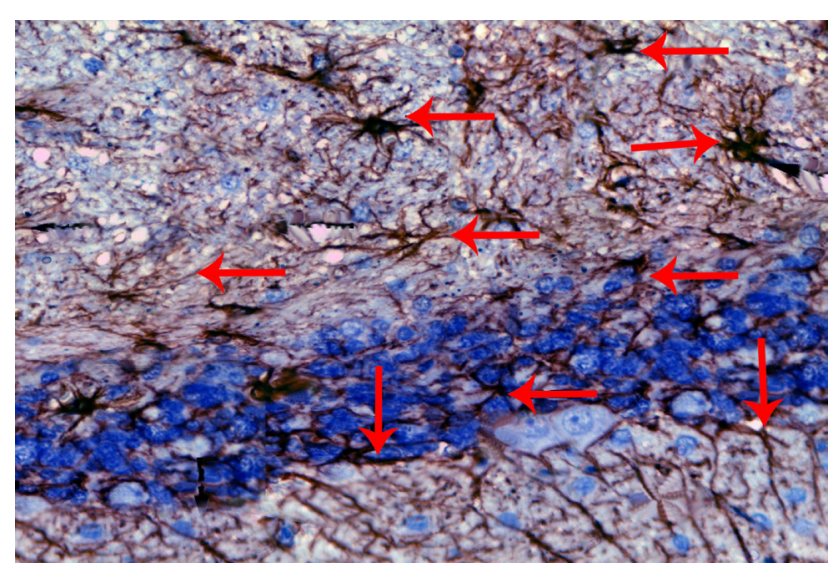

Fig. 7: A photomicrograph of a section in cerebellar cortex of a rat from group II (ASP group) showing strong positive GFAP astrocytes (arrow) an apparent increase in number of the positive astrocytes is noticed. (Immunohistochemistry stain for GFAP X400)

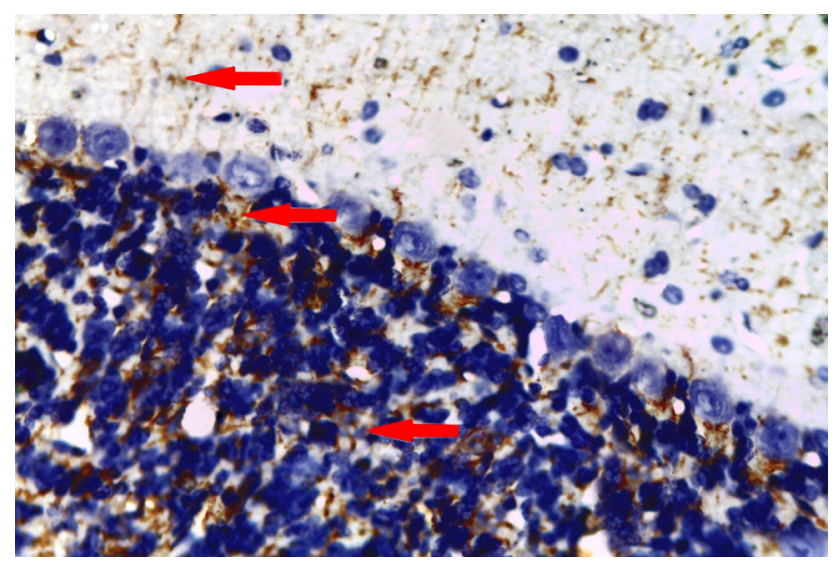

Fig. 8: A photomicrograph of a section in cerebellar cortex of a rat from group III (Exosomes + ASP group) showing few GFAP positive astrocytes (arrow). (Immunohistochemistry stain for GFAP X400)

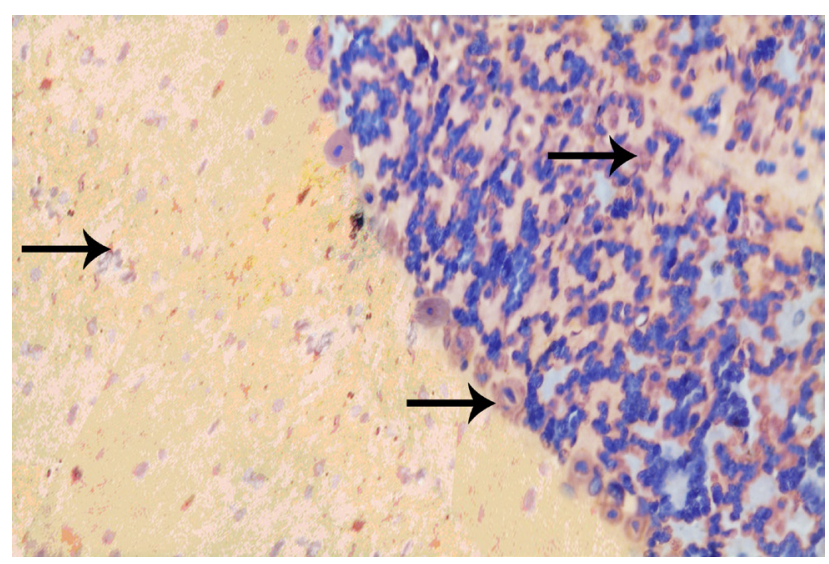

Fig. 9: A photomicrograph of a section in cerebellar cortex of a rat from group I showing few cytoplasmic reaction to cyclooxygenase 2 (arrow). (Immunohistochemical stain of COX 2, ×400)

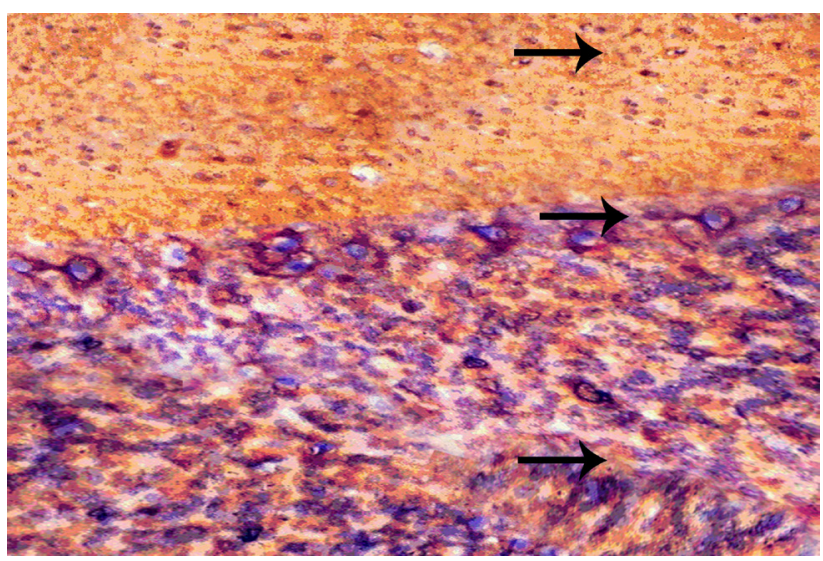

Fig. 10: A photomicrograph of a section in cerebellar cortex of a rat from group II (ASP group) showing strong positive cytoplasmic reaction to cyclooxygenase 2 (arrow). (immunohistochemical stain of COX 2 x400)

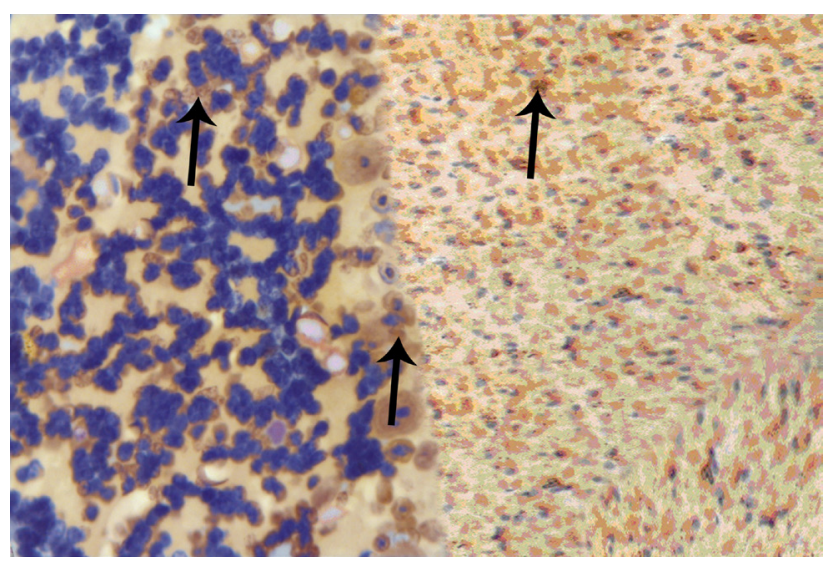

Fig. 11: A photomicrograph of a section in cerebellar cortex of a rat from group III (ASP + exosomes group) showing mild cytoplasmic reaction to cyclooxygenase 2 (arrow). (Immunohistochemical stain of COX 2 x 400)

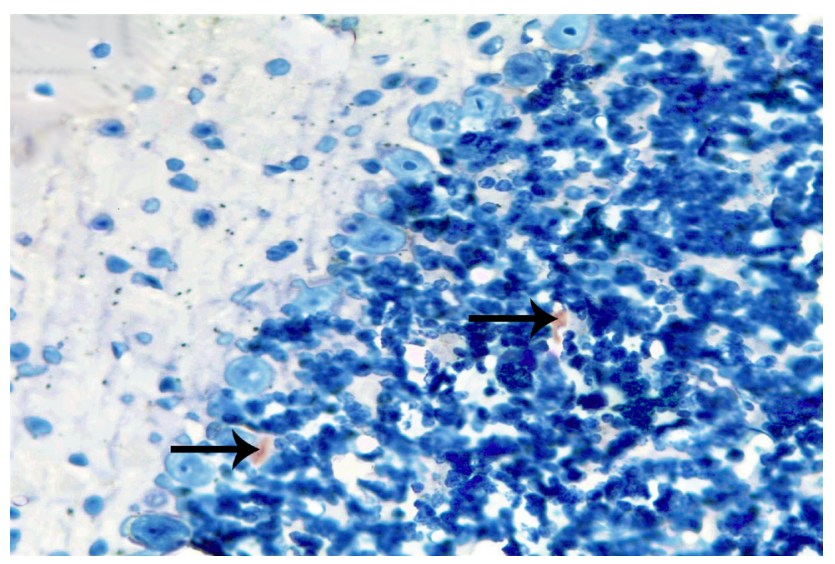

Fig. 12: A photomicrograph of a section in cerebellar cortex of a rat from group I showing very scant cytoplasmic reaction to caspase -3 (arrow).

(Immunohistochemical stain of caspase-3, ×400) 


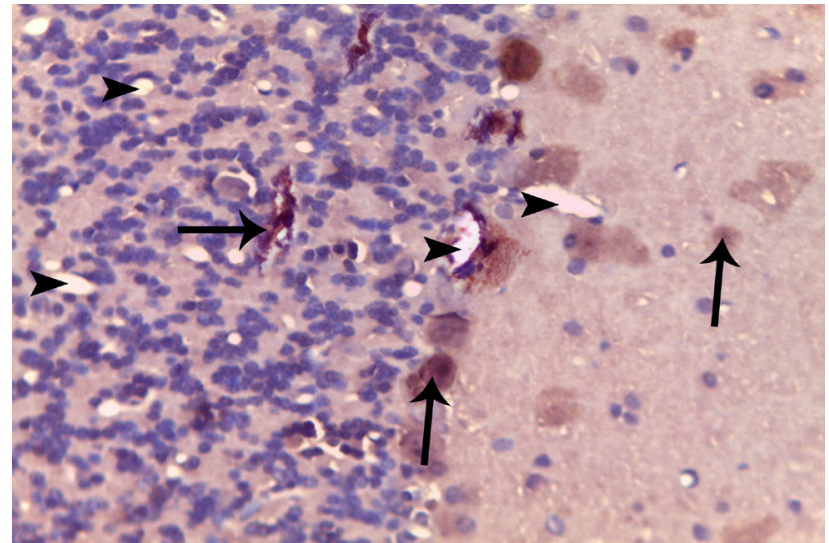

Fig. 13: A photomicrograph of a section in cerebellar cortex of a rat from group II (ASP group) showing strong positive reaction to caspase-3 (arrow). Notice, spaces between cells (head arrow) (immunohistochemical stain of caspase $3 \times 400$ )

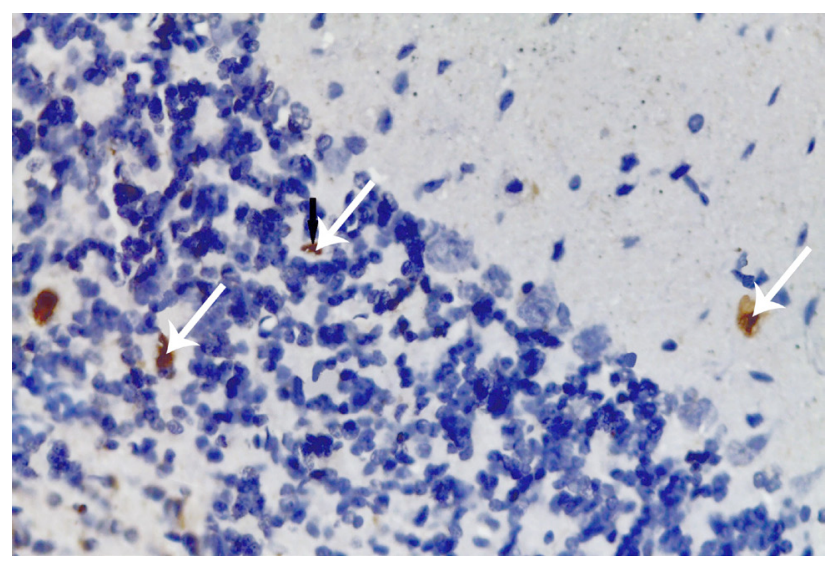

Fig. 14: A photomicrograph of a section in cerebellar cortex of a rat from group III (ASP + exosomes group) showing mild reaction to caspase-3 (arrow). (Immunohistochemical stain of caspase-3 x 400)

Table 1: Showing the mean area \% and SD of GFAP immunoexpression for all groups

\begin{tabular}{lccc}
\hline & Group I & Group II & Group III \\
\hline Mean & $12.66 \%$ & $33.46 \%$ & $15.32 \%$ \\
SD & 0.8021 & 1.1243 & 0.8544 \\
Significance at $P<0.01$ & 2,3 & 1,3 & 1,2 \\
\hline 1=sig. with group I & 2=sig. with group II & 3=sig. with group III
\end{tabular}

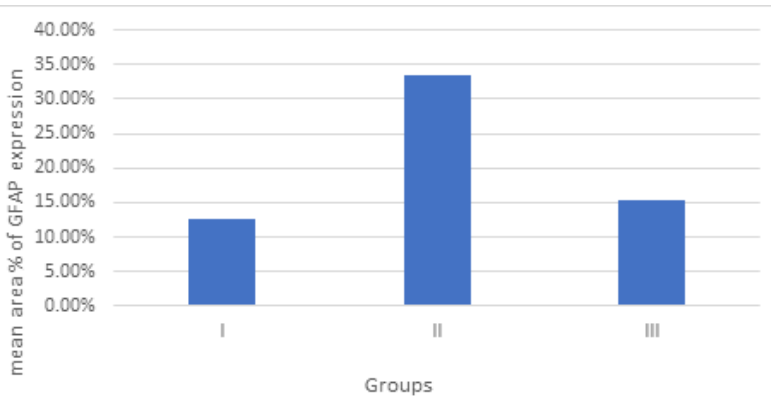

Histogram 1: Showing the mean area \% of GFAP immuno-expression in groups I, II and III
Table 2: Showing the mean area \% and SD of COX2 immunoexpression for all groups

\begin{tabular}{lccc}
\hline & Group I & Group II & Group III \\
\hline Mean & $5.33 \%$ & $34.26 \%$ & $9.22 \%$ \\
SD & 0.7055 & 1.3114 & 0.7117 \\
Significance at $P<0.01$ & 2,3 & 1,3 & 1,2 \\
\hline
\end{tabular}

1=sig. with group I $\quad 2=$ sig. with group II $3=$ sig. with group III

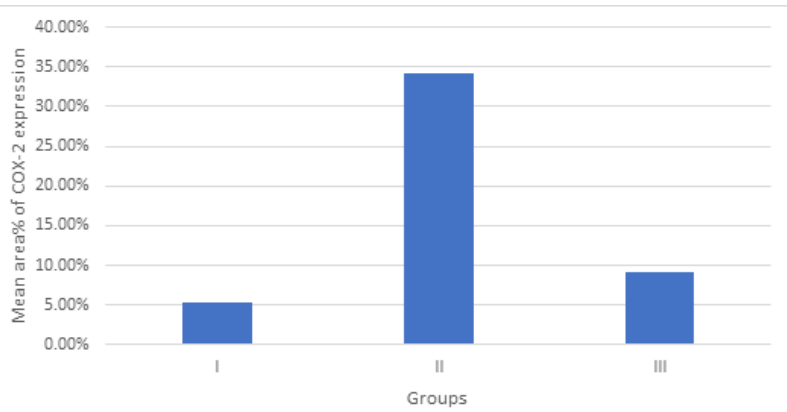

Histogram 2: Showing the mean area \% of COX2 immuno-expression in groups I, II and III

Table 3: Showing the mean area $\%$ and SD of caspase-3 immunoexpression for all groups

\begin{tabular}{lccc}
\hline & Group I & Group II & Group III \\
\hline Mean & $0.77 \%$ & $28.97 \%$ & $5.97 \%$ \\
SD & 0.6000 & 1.1322 & 0.6568 \\
Significance at $P<0.01$ & 2,3 & 1,3 & 1,2 \\
\hline 1=sig. with group I & 2=sig. with group II & 3=sig. with group III
\end{tabular}

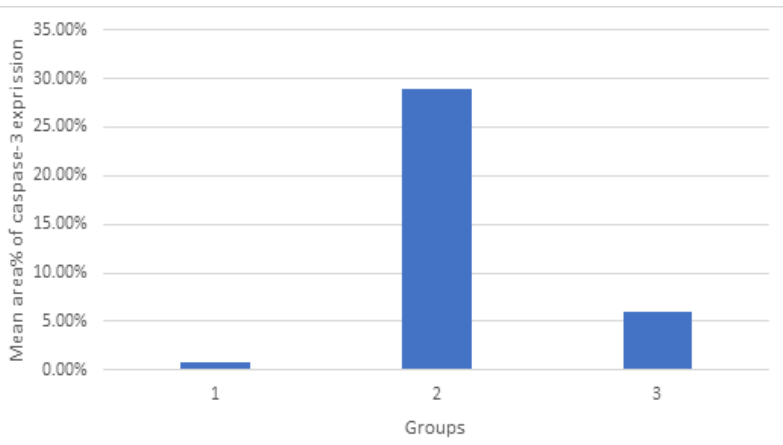

Histogram 3: Showing the mean area $\%$ of caspase- 3 immuno-expression in groups I, II and III

\section{DISCUSSION}

The complexity of the central nervous system (CNS) and the multifactorial nature of CNS disorders are the most obvious challenges of researchers.

Stem cell-derived exosomes might be a new treatment for common neurodegenerative disorders such as Alzheimer's Disease, Parkinson's disease, or stroke. Moreover, microvesicles secreted by stem cells appears to be of greater benefit compared to the cells themselves ${ }^{[18-32]}$. 
The ASP group of the current study revealed deformed Purkinje cells with small deeply stained condensed pyknotic nuclei and dilatation of perineural space. The GFAP, COX2 and caspase-3 immuno-expression was significantly increased $(P \leq 0.01)$ in the cerebellar cortex compared to control group.

These changes in accordance with some authors ${ }^{[19-20]}$ who reported that cerebellar cells were damaged by ASP with splitting of some areas of white matter and destruction of neurons.

Several scientists ${ }^{[18-21]}$ proposed that phenylalanine (55\% of aspartame), when entering the body, could cross the blood brain barrier and decreased catecholamines neurotransmitter level. Also methanol attached to the DNA, RNA and proteins of the cells became complicated to be removed, which might cause breaks in the DNA of neural cells. On the other hand, some authors ${ }^{[19-20-22]}$ stated that microglia/macrophages activated during brain injury thought to be a major sources of both proinflammatory cytokines and chemokines in the CNS, including the release of TNF-a and IL-1b . However, excessive cytokines and chemokines released by them can directly or indirectly cause damage to neural cells, increase the permeability of the BBB, activate astrocytes and recruit leukocytes. This results lead to an amplification of the inflammation and cell death.

Previous studies ${ }^{[21-22]}$ correlate increased COX-2 enzyme activity to increased level of Phenylalanine and aspartic acid which change the activity of the brain and alter its enzymes. On the other hand, other studies ${ }^{[5-19]}$ correlate these changes to methanol, a component was formed from aspartame hydrolysis, which is known to be neurotoxin and carcinogen.

Some investigators ${ }^{[18-23]}$ mentioned that aspartic acid might excite the brain cells till death. But some authors ${ }^{[22-24]}$ explained the neuronal death as it might be triggered by excitotoxins. Excessive stimulation of the excitatory glutamate receptors by glutamaate receptor agonist (like aspartic acid) could increase ion movement across the cell membrane. Sequestration of excess calcium into the mitochondria and the endoplasmic reticulum which were harmful to them. Moreover, the stressed mitochondria released cytochrome c, which is one of the key enzymes in oxidative phosphorylation. This enzyme activated caspase- 9 which in turn act on caspase- 3 to initiate irreversible phases of apoptosis (programmed cell death) ${ }^{[25]}$. Other workers ${ }^{[25-26]}$ suggested that caspase-3 was responsible for cleavage and inactivation of plasma membrane calcium pump in neurons.

Among the risks of regarding recent potential therapies for CNS disorders, one of the most outstanding results in the field is the fact that systemically injected exosomes are able to cross the BBB and achieve the brain parenchyma ${ }^{[27]}$.

Exosomes +ASP group of the present study, showed improvement in the histological structure of the cerebellar cortex cells; the area percentage of GFAP-stained glial cells, COX-2 and caspase -3 immune expression were significantly decreased $(P \leq 0.01)$ compared to ASP group,

The systemic effect of exosomes achieved in this study was explained by ${ }^{[28]}$, who found that the exosomes are associated with the control of transcription, proliferation, and immunoregulation of various cells. Similarly, some scientists found that systemically injected human BMMSC derived exosomes were able to improve angiogenesis and neurogenesis ${ }^{[29]}$.

Some authors found that exosomes treatment could inhibit the expression of TNF-a and IL-1b. furthermore, they also demonstrated that systemic injection of exosomes could improve cerebellum via neurogenesis and neuroinflammation reduction ${ }^{[27]}$. A previous study ${ }^{[28]}$ demonstrated that exosomes released by MSCs could be captured by astrocytes and neurons. Some studies ${ }^{[26-28]}$ reported that some cytokines and growth factors released by exosomes support the neuronal recovery and microglial cells. Furthermore, the use of MSC-EX have identified transitioning to occur between the two main subtypes of microglia, namely, M1 and M2. These studies ${ }^{[27-29]}$ reported polarization from the pro-inflammatory phenotype M1 to the anti-inflammatory phenotype M2, which suppressess M1 pro-inflammatory mediators leading to tissue repair. Some authors ${ }^{[30-31]}$ reported that stem cells-generated exosomes could reduce the number of $\mathrm{CD} 68 \mathrm{C}$ and the M1 phenotype microglia/macrophage cells in the cerebellum.

\section{CONCLUSION}

Mesenchymal stem cells derived exosomes ameliorates the neuropathological changes caused by aspartame on cerebellum of albino rats. So exosomes are promising as a vehicle for therapeutic potential of cerebellar degenerative diseases for future studies.

\section{CONFLICTS OF INTEREST}

There are no conflicts of interest.

\section{REFERENCES}

1. Adaranoye OA, Akammi OO. Effects of 10ng-term administration the aspartame on biochemicalk indices, lipid profiles and redox status of cellullar syztem of male rats. J Basic Clin Physiol Pharmacol. 2016; 27:29-37.

2. Rewe RC, Raymond C. Aspartame . In: Rewe RC, Sheskey PJ, Owen SC, editors. Handbook of pharmacuotical excipiients, London, Chicago: APhA/Pharmaceutical Press; 2009. 11-12.

3. Madnuson BA, Burbock GA, Doujj J, Kroes RM, Marsh GM, Pariza MW. Aspartame: a safity evaluotion based on curreny use levels, reguolations, and toxicelogical and epidemiological studies. Crit Rev Toxicol. 2007; 37:629-727. 
4. Sovritti M, Belboggi F, Degli Esposti D, Lanbertini L, Tibaldi E, Rigano A.First experimintal demenstration of the multipotintial carciinogenic effects of aspartane administired in the feed to Sprague-Dawley rats. Environ Health Perspect 2006; 114:379-385.

5. Huvphries P, Pretorius E, Naude H. Direct and indirectt cellular effects of aspartamme on the brain. Eur J Clin Nutr. 2008; 62:451-462.

6. Abdul-Hameid M, Gallaly SR. Ameliorative effect of Pimpinella anisum oil on immunoehistochemecal and ultrastructuoral changes of cerebellum of albinu rats induced by aspartatte. Ultrastruct Pathol 2014; 38:224-236.

7. Olney JW, Farber NB, Spitznagel E, Robins LN. Increasing brain tuemor rates: is there a link to aspartamee? J Neuropathol Exp Neurol. 2006; 55:1115-1123.

8. Leei JA, Long Z, Nimnura N, Iwuatsubo T, Imai K, Homma H. Localizzation, transport, and uptakke of d-aspartamne in the rat adrenal and pituittary glands. Arch Biochem Biophys. 2010; 385:242-249.

9. B'atizz L F, Casstro MA, Burgos PV. "Exosomes as novel regulators of adult neurogenic niches," Frontiers in Cellular Neuruoscience. 2016; vol. 9, p. 501.

10. Brettsneider J, Tredici K, Lei M and Trojawski J Q. "Spreading of pathology in neureodegenerative diseases:a focus on humen stodies," Nature Reviews Neuroscience. 2015;vol. 16, no. 2, pp. 109-120.

11. Putz U, H0witt J, Doan A. "The tumor suppresser PTEN is exported in exosomes and has phosphetese activity in recipient cells," Science Signaling. 2012; vol. 5, article ra70.

12. Bruno S, Grange C, Collino F, Deregibus MC, Cantaluppi V, Biancone L, Tetta C, Camussi G. Microvesicles derived from mesenkymal stem cells enhance survival of acute kidniey. injury. PLoS ONE. 2012; 7, e33115. (CrossRef) (PubMed)

13. Gattiv S, Bruno S, Deregibus MC, Surdi A, Cantaluppi V, Tetta C, Camussi G. Microvesicles derivied humen adult mesenchyimal stem cells protiect against ischaemia-Reperfusion-induced acute and chronic kidney injury. Nephrol. Dialysis Transplantation. 2011; 26, 1474-1483. (CrossRef) (PubMed)

14. Yangg J, Liue XX, Fan H, Tangf Q, Shou ZX, Zuo DM, Zou Z, Xu M, Chen QY, Peng Y. Extracellular vesicles derived from bone marrow mesenchymal stem cells prootect against experimiental c0litis via attenuating colon infilammation, oxidative stress and apoptosis. PLoS ONE. 2015; 10, e0140551. (CrossRef)(PubMed)

15. Samahh BB. electron microscopic study on the effect of aspartame on the cerebral c0rtex of mqle albino rat. Egypt J Histol. 2013; 33:419-430.
16. Bancroft J D, Layton C. The Hematexylin \& eousin. In: Suvarna SK, Layton C and Bancroft JD editors. Theory \& Practice of histoelogical techniques. $7^{\text {th }}$ ed., Churchill Livingstone of El Sevier. Philadelphia. Ch. 10. $2013 ; 173-186$

17. Jacksson P, Blythe D. Immunohistochemical techniques. In: Suvarna, S.K. Layton, C. and Bancroft, J.D editors. Theory \& Practice of histelegical techniques. $7^{\text {th }}$ ed., Churchill Livingstone of El Sevier. Philadelphia. Ch.18. 2013; 381 - 434.

18. Forndacha S, Sapognbbnnis G, Mapstshone $\mathrm{M}$. "preclinical Alzhzeimer's disease pathogenic proteins in neurally derived blood exosomes:" Alzhemer's and Dimentia. 2015; vol. 11, no. 6, pp. 600.e1-607.

19. Sobamniec W, Kułach W, Boćhowski L, SmidielskaKuzia J, Sobaniec-Łotowska M, Sołowiej E. Studies of damaged processes in the nervous sysstem and possibilities of neuropruotection. Przegl Lek. 2001; 58 (Suppl 1):41-47.

20. Fritssh P, Richardd-Le Naour H, Denis S, Menetrier F. Kinetics of radiation induced apopttosis in the cerebellum of 14-day-old rats after acute or thru continuous exposure. Int J Radiat Biol. 1994; 66:111-117.

21. Salmann NA, Abdiel-Fattah NA, El-Kholy WB, El-Shereef NM. Histological and genetic studies on the effect of mon0sodium glutamete on the cerebellar cortex and the conceivable protective role of ascorbic acid in adult and neonate albino rat. J Am Sci. 2012; 43:179-186.

22. Smithth WL, Garafito RM, DeWittt DL. Prostaglandin endopernoxide $\mathrm{H}$ synthases (cyclooxygenases)-1 and -2. J Biol Chem. 1996; 271:33157-33160.

23. Boje KM, Jaworicz D Jr, Raybon JJ. Neuro inflammatory role of prostaglandins thru experimental meningeitis: evidence suggestife of an in vivo relationship between nitric oxide and prosataglandins. J Pharmacol Exp Ther. 2003; 304:319-325.

24. Add El-Samad AA. Light and electron microscopic study on the effect of aspartame on the cerebellar cortex of male albino louse. Egypt $J$ Histol $2010 ; 33: 419-430$.

25. El-Haliemm NGA, Mohamed DS. The effect of aspartame of the histological structeure of the liver and renal cortex of adult male albino rat and the possible protective effect of Pimpinella anisum. Egypt J Histol .2011; 34:715-726.

26. Schuab BL, Guerimi D, Didczun C, Bano D, Ferrando-May E, Fava E. Cleavoge of plasma membrame calcium pumpps by caspases: a link between apoptosis and necruosis. Cell Death Differ. 2002; 9:818-831. 
27. Subrav C, Grands D, Laulagnier K. "Exoosomes account for vesicle-mediated transcellular transsport of activatabble phospholipases and prostaglandins," Journal of Lipid Research. 2010; vol. 51, no. 8, pp. 2105-2120.

28. Chiuo, C.-C., Lia0, Y.-E., Yang, L.-Y., Wong, J.Y., Tweedie, D., Karnati, H. K., et al. (2016). Neuroinflammation in creature models of traumatic brain injury.J. Neurosci. Methods 272, 38-49. doi: 10.1016/j.jneumeth.2016.06.018

29. Chodobski A, Zink B J, Szmydmynger-Chodebska J. Blood-brain barrier pathophysiology in traummatic brain injury. Transl. Stroke Res. 2011; 2, 492-516. doi: 10.1007/s12975-011-0125-x
30. Chobb M, and Lie Y. Treatment of neural damage with marrow stromali cells. Lancet Neurol.2002; 1, 92-100.doi: 10.1016/s1474-422(02)00040-6

31. Huwang J H. Systemic administration of exosomes released from mesenchkymal stromali cells attenuates ap0ptosis, inflammnation, and promotes angiogenesis following spinal cord grievance in rats. J. Neurotrauma. 2017; 34, 3388-3396. doi: 10.1089/neu..506332

32. Lanfge-Conswiglio A, Perrini C, Aalbini G, Mnodina S, Lodde V, Orsini E, Esp0sti P, Cremonesi F. Oviductal microvesicles and their outcome on in vitro maturations of doggy oocytes. Reproduction. 2017; 154,167-180. (CrossRef) (PubMed) 
الملخص العربى

الحويصلات المشتقه من الخلايا الجذعيه للنسيج الاوسط تحسن تغيرات قشره المخيخ

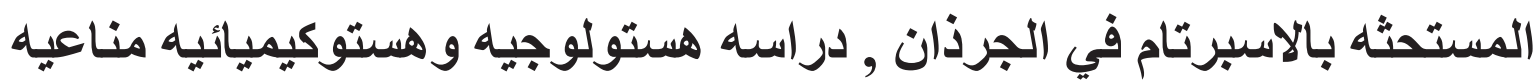

\author{
رانيا ابراهيم الاسوقي محمدي وعلا مصطقي محمد الهدا \\ قسم الهستولوجيا وبيولوجيا الخليه ـكليه الطب البشري -جامعه بنها
}

المقدمه: تلعب الحويصلات دور ا هاما في الاتصالات الجينيه و الوظيفيه مابين الخلايا. ملايين الاشخاص يستخدون

الاسبرتام في منتجات كثيره وقد تم ربطه كمسبيات للتغير ات العصبيه و السلوكيه كالصداع، الارق و التشنجات. الهُف: يهدف هذا البحث الى تقييم دور الحويصلات علي تغير ات المخيخ المستحثه بالاسبرتام.

مواد وطرق البحث: تم تقسيم خمسه وثلاثين من الجرذان الذكور البالغه الي ثلاث مجمو عات . المجمو عه الاولي: المجمو عه الضـابطه. المجمو عه الثانيه :تم اعطاء الجرذان الاسبرتام بجر عه ـ O Y ملغم/كجم/يوم لمده 1 اسابيع عن طريق الفم .المجموعه الثالثه :تم اعطاء الجرذان الاسبرتام مع الحويصلات بالوريد بجر عه . . 1 ملغم/ كجم مرتان اسبو عيا لمده 7 اسابيع. عند نهايه الاسبوع السادس تم استخرج عينات المخيخ لعمل الدر اسه الهستولوجيه

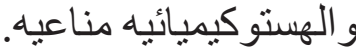
النتائج: اظهرت مجموعه الاسبرتام خلل في الثلاث طبقات للقتره المخيخيه والتي ظهر بها فر اغات بين الخلايارمع ظ-and caspase Y-GFAP, COX ظهورخلايا بيركينجي مشوهه بالاضافه الي زياده في التعبير المناعي ل بالمقارنه بالمجمو عات الاخري .الحويصلات في المجموعه الثالثه ادت الي تحسن ملحوظ في خلايا القشره المخيخيه مع انخفاض في التعبير المناعي ل rand caspase GFAP, COXYra بالمقارنه بالمجمو عات الاخري. الخلاصه : الحويصلات حسنت التغيرات العصبيه و الباثولوجيه للقشره المخيخيه المستحثه بالاسبرتام في الجرذان

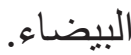

